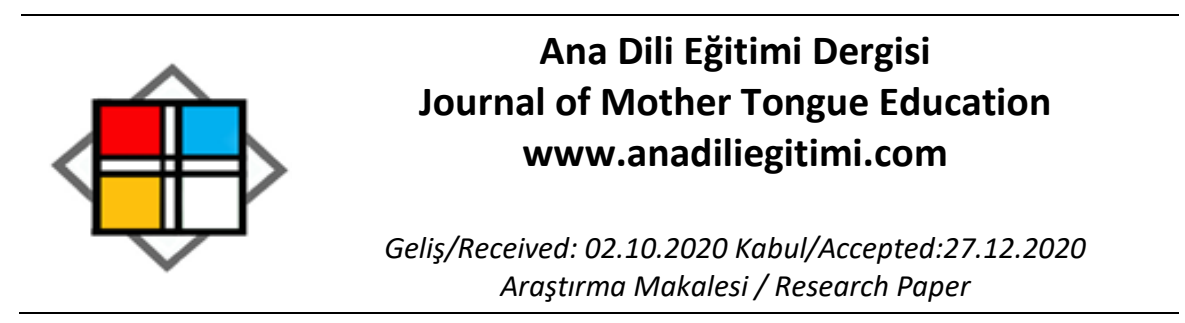

\title{
Ana Dili Türkçe Olmayan Mülteci Çocuklarda Kelime Tanıma Envanterinin Kullanımı*
}

\begin{abstract}
Ayşegül AVŞAR TUNCAY**
Öz

Illkokul birinci sınıfa başlayan mülteci çocuklar, aynı dili konuşmadığı akranlarıyla birlikte aynı sınıfta okuma-yazmayı öğrenmeye çalışmaktadır. Birinci sınıfta, okumanın anlamlı hâle gelmesi için sınıf öğretmeni tarafından bireysel farklılıkların dikkate alınıp öğrencilerin kelime tanıma düzeylerine göre okuma parçalarına yönlendirilmesi gerekmektedir. Bu gerekçeyle ilkokul birinci sınıflarda mülteci çocukların da kullanabilecekleri, Kelime Tanıma Envanteri (KTE) adı altında öğrencilerin kelime tanıma düzeylerini belirleyen bir ölçme aracı geliştirilmiştir. KTE, ilkokul birinci sınıf öğrencilerinin ders kitaplarında yer alan ve günlük yaşantılarında sık kullanılan kelimelerden oluşan, dik temel yazıyla hazırlanmış her biri 20 kelimeden oluşan 40 adet kelime listesinden meydana gelmektedir. Tasarım ve geliştirme araştırma modelinin Tip 1 türünün kullanıldığı araştırmanın çalışma grubunu; uygun örnekleme yöntemiyle seçilmiş sosyoekonomik durumları farklı iki devlet okulunda öğrenim görmekte olan 32 Suriyeli mülteci ilkokul öğrencisi oluşturmaktadır. Veri toplama araçları olarak; KTE ve Kelime Tanıma Çizelgesi kullanılmıştır. Araştırma sonucunda envanterin; öğrencilerin okuma motivasyonunu arttırdığı, öğrencilerin kelime tanıma düzeyleri üzerinde olumlu yönde etkisinin olduğu, belirli bir rutin ve düzen çerçevesinde okutulduğunda mülteci çocuklarda da süreklilik sağladığı sonucuna ulaşılmışır.
\end{abstract}

Anahtar Kelimeler: Suriyeli mülteci çocuklar, ilkokul birinci sınıf, kelime tanımayı değerlendirme, kelime tanıma envanteri

\section{Use of Word Recognition Inventory with Primary School First Class Syrian Refugee Children whose Mother Tongue is not Turkish}

\begin{abstract}
Refugee children starting the first grade of primary school try to learn to read and write in the same class with their peers who do not speak the same language. In the first grade, in order for reading to become meaningful, individual differences should be taken into account by teacher and should be directed to the reading texts according to the students' level of word recognition. For this reason, a measurement tool was developed under the name of the Word Recognition Inventory (WRI), which can be used by refugee children in the first grade of primary school, and determines the word recognition levels of students. World Recognition Inventory consists of a list of 40 words, each consisting of 20 words, prepared in non-italic letters, which are included in the textbooks of primary school first-year students and consist of words frequently used in their daily lives. 32 Syrian refugee primary school students who are studying at two public schools are selected by appropriate sampling method, constitute the study group of the study in which the Type 1 type of the design and development research model was used. As data collection tools; Word Recognition Inventory and Word Recognition Chart. As data collection tools; WRI and Word Recognition Chart were used. As a result of the research, it was concluded that the inventory increased students 'reading motivation, had a positive effect on students' word recognition
\end{abstract}

\footnotetext{
${ }^{*}$ Araştırmanın etik kurulu izni: Hacettepe Üniversitesi, 26.07.2016, 35853172/433-2359.

** Dr. Öğr. Üyesi, Mersin Üniversitesi, Eğitim Fakültesi, Özel Eğitim Bölümü, Mersin, aysegulaat@mersin.edu.tr, ORCID: 0000-0002-0520-1747
} 
levels, and provided continuity in refugee children when they were taught within a certain routine and order.

Keywords: Syrian refugee children, primary school first grade, word recognition assessment, word recognition inventory

\section{Giriş}

Türkiye, tarihinin en büyük göç hareketini, Suriyeli vatandaşların demokrasi ve reform istekleriyle başlayan karışıklıklar sonucu Mart 2011'de yaşamıştır. Bu süreçte yaklaşık 4 milyona yakın Suriyeli mülteci ülke dışına göç etmek durumunda kalmış, 6 milyona yakını evlerini terk ederek ülke içinde güvenli bölgelere yerleşmiştir (Ağır ve Sezik, 2015). Türkiye bu süreçte açık kapı politikası uygulayarak, mültecilere yardım yapmış ve yapmaya da devam etmektedir (Akpınar, 2017).

Mültecilerin toplumsal uyum sürecini düşünürsek bundan olumlu veya olumsuz en çok etkilenen kitlelerden biri de çocuklardır. Mülteci çocuklar günlük yaşamlarını sürdürebilmek amacıyla çeşitli destek almaktadırlar fakat eğitim konusunda sıkıntılar yaşamaları gelecekte hem ülke vatandaşı için hem de kendileri için büyük tehditler oluşturulabilir. Benzer biçimde Seydi (2014) Suriye'deki çatışmaların en fazla etkilediği konuların başında çocuk ve gençlerin eğitim süreçleri olduğunu ifade etmektedir. Özellikle mülteciler içerisinde çocukların büyük bir çoğunluğu (\%45) oluşturması, öğrenim çağındaki çocukların eğitimine dikkat çekilmesini zorunlu hale getirmektedir (Sağlam ve ilksenKanbur, 2017). Eğitimin, bireylerin diğer temel haklarına da erişmelerini mümkün kılan en önemli haklardan bir tanesi olduğu düşünülürse (Sinclair, 2001), eğitim göç etmek zorunda kalan mülteciler için ayrıca bir önem arz etmektedir.

Türkiye'de yabancı öğrencilerin eğitimine yönelik izlenmesi gereken hususlar Türkiye Cumhuriyeti Millî Eğitim Bakanlığı tarafından yayımlanan Yabancılara Yönelik Eğitim-Öğretim Hizmetleri genelgesinde belirtilmiştir. Suriyeli mülteci çocuklara yönelik eğitim hizmetlerini yürütmek üzere 2018 yılında Türkiye Cumhuriyeti Millî Eğitim Bakanlığı Hayat Boyu Öğrenme Genel Müdürlüğü’ne (HBOGM) bağıı Göç ve Acil Durum Eğitim Başkanlığı kurulmuştur (HBOGM, 2020). HBOGM, okul çağındaki çocukların resmi okullara yönlendirilmesi, anaokulu ve birinci sınıfa kayıtların zorunlu hale gelmesi, ara sınıf öğrencileri için yoğun Türkçe eğitimi sağlanmasına yönelik çalışmalar yapmıştır (Tuğluk ve Avcı, 2018). Eğitim alabilecekleri kurumlar arasında yer alan devlet okulları, Suriyeli mülteci çocukların en çok tercih ettikleri alternatifler arasındadır. Diğer alternatifler ise; geçici eğitim merkezleri, Suriyeliler tarafından açılan özel eğitim kurumları ve Suriyelilere yönelik yaygın eğitim hizmetleri veren kurumlardır (Emin, 2016). Devlet okullarının yaygın olması, ücretsiz ve karma bir ortam sunması Suriyeli mülteci çocukların eğitimi konusunda tercih edilme nedenlerindeki önemini de arttırmaktadır. Türkiye Cumhuriyeti Millî Eğitim Bakanlığı tarafından 2017'den itibaren kademeli olarak resmi okullara kaydedilen gruplar arasında yer alan ilkokul birinci sınıf öğrencileri, ara sınıf öğrencileri gibi yoğun Türkçe eğitimine tabi tutulmadıkları için aynı dili konuşmadıkları akranlarıyla birlikte öğrenim görmektedirler. Evde ebeveynlerinin Türkçe bile konuşmadığı bu çocuklar, yaşıtlarıyla birlikte aynı sınıfta okuma-yazmayı öğrenmeye çalışmaktadırlar. Zorunlu eğitim çağındaki Suriyeli mülteci çocuklara eğitim öğretim fırsatlarının sağlandığı devlet okullarında, özellikle ilkokul birinci sınıfta öğrenim görmek çocuklar için hiç de kolay olmamaktadır.

Okul hayatının en önemli dönemlerinden biri olan ilkokul birinci sınıfta öğrencinin temel öğrenme intiyaçlarının başında okuma-yazmayı öğrenme gelmektedir. Son derece karmaşık bir beceri olan okuma-yazma süreci iki öğeden oluşmaktadır. Bu öğelerden biri, okunan kelimenin tanınması, diğeri ise okunan kelimenin anlamının bilinmesidir. Çocukların yalnızca okuduğu ve yazdığı kelimeleri anlayabilecekleri bir dilde okuma yazma öğrenebildikleri düşünüldüğünde (Öztunç, 1994); sosyal yaşantılarında ve aile içerisinde duyduğu kelimeleri yazılı olarak görmeleri, çocukların kelimeyi anlamlandırmalarını kolaylaştıracaktır (Avşar Tuncay, 2017). Bu durum, ana dili Türkçe olmayan mülteci çocukların hem Türkçeyi hem de okuma-yazmayı öğrenmeleri için zorlayıcı olmaktadır. Sosyal çevrelerinde konuşulan dil ve çevrelerinde yer alan görseller kelimeyi tanıma evresinde anlamlandırmalarını geciktirebilir. Dolayısıyla mülteci çocukların hem görsel hem de yazılı olarak Türkçe kelimelere maruz bırakılıp kelime tanımalarının otomatikleşmesini sağlamak gerekmektedir. 
Bir sınıf öğretmeni için öğrencisinin okuma metninde geçen kelimeyi tanıması ve okumayı anlamlandırması son derece önemlidir. Kelime tanımanın anlamlandırma için önemli olduğu dönemlerden biri olan ilkokul yılları, öğretmen ve öğrenci için bazı anların sancılı geçtiği dönemlerdir. Özellikle Türkçe Dersi Öğretim Programı́na göre, ilkokul birinci sınıfta ses gruplarının belirli bir zaman diliminde verilme zorunluluğu öğretmen ve öğrenci için birtakım sorunlar teşkil etmektedir. Öğretmen, öğrencinin o ses grubuyla oluşturulan kelimeleri okuyup okuyamadığını tespit edemeden ses grubunu tamamlayıp zaman kısıtlamasından dolayı diğer ses grubunu işlemeye devam etmektedir. Ses grubuyla oluşturulan kelimeleri tam olarak okuyamadan diğer ses grubuna geçen öğrenci için bu sorun ses grupları tamamlanıncaya kadar katlanarak devam etmektedir. Bu nedenle diğer ses gruplarına geçmeden önce tamamlanan her ses grubunu öğrencinin eksiksiz okuyup okuyamadığını ortaya koymak adına öğrencilerde bireysel olarak kullanılabilecek bir değerlendirme aracının olması gerekmektedir. Bu gerekçeyle öğrencilerin kelime tanımada bağımsız, öğretimsel ve endişe düzeylerinden hangisinde yer aldığı belirlenebilecek, kelime tanıma düzeylerine göre öğrencilerin okuma parçalarına yönlendirilmesi sağlanabilecektir. illkokul birinci sınıflarda mülteci çocukların da kullanabilecekleri, Avşar Tuncay (2017) tarafından "Kelime Tanıma Envanteri" (KTE) adı altında geliştirilen bir değerlendirme aracı ile öğrencilerin kelime tanıma becerilerini, kelime tanımanın otomatikliğini belirlemek ve değerlendirmek mümkün olabilmektedir. Daha önce ilkokul birinci sınıflarda uygulanan KTE'nin öğrencilerin kelime tanıma düzeylerini belirleyerek kelime tanıma becerilerinin değerlendirilmesine ve bireysel intiyaçlarına uygun olan okuma çalışmalarının yapılmasına katkı sağladığı görülmektedir (Avşar Tuncay ve Dedeoğlu, 2020). Ana dili Türkçe olmayan ilkokul birinci sınıf mülteci öğrencilerde uygulanan bu çalışmanın KTE'nin mülteci öğrencilerin Türkçe kelimeyi tanımasında ve öğretmenlere öğrencinin kelime tanıma becerisinin değerlendirilmesinde yardımcı olacağı düşünülmektedir. Bu araştırmanın amacı; sürece dayalı olarak hazırlanan ve değerlendirilen, iyi bir ölçme aracı niteliklerini taşıyan ve öğrencilerin kelime tanıma düzeylerini tespit etmeye yönelik geliştirilen KTE'nin ilkokul birinci sınıf mülteci çocukların Türkçe kelimeleri tanıma düzeylerini belirlemede etkililiğini ortaya koymaktır.

\section{Araştırma Modeli}

\section{Yöntem}

Bu araştırmada ilkokul birinci sınıf mülteci çocukların Türkçe kelimeleri tanıma düzeylerini belirlemeye yönelik geliştirilen bir aracın uygulanması bakımından tasarım ve geliştirme araştırma modelinin Tip 1 Ürün ve Araç Araştırması türü kullanılmıştır. Eğitimde kullanılmak üzere yeni bir aracın geliştirildiği ve geliştirilen aracın okullarda uygulanabilirliğinin, eğitim bakımından çocuk üzerindeki etkililik ve verimliliğinin ortaya konduğu araştırmalar 'tasarım ve geliştirme araştırması (TGA)' olarak adlandırılmaktadır (Richey ve Klein, 2008). Büyüköztürk, Kılıç-Çakmak, Akgün, Karadeniz ve Demirel (2016) TGA'yı Tip-1 ve Tip-2 olmak üzere iki kategoride toplamıştır. Tip-1'de eğitimde kullanılmak üzere bir araç geliştirilip uygulanabilirliği test edilirken; Tip-2'de araç yerine model geliştirilip uygulanabilirliği test edilir. Tip-1 türünde eğitimde kullanılacak aracın geliştirilme süreci üç aşamadan oluşur. Bunlar; analiz, araç geliştirme, son olarak da aracın değerlendirilme aşaması olarak tanımlanabilir (Mutlu, 2016). Yeni ürün olarak Avşar Tuncay (2017) tarafından tasarlanan ve geçerliğigüvenirliği test edilip uygulanabilirliği denenmiş olan KTE'nin mülteci birinci sınıf öğrencilerde kullanıldığı bu araştırmanın yapı bakımından tasarım ve geliştirme araştırma modelinin Tip-1 Ürün ve Araç Araştırması türüne uygun olduğu görülmektedir.

\section{Araştırma grubu}

Araştırmanın çalışma grubunu; iki devlet okulunda öğrenim görmekte olan ve uygun örnekleme yöntemiyle seçilmiş 32 Suriyeli mülteci ilkokul birinci sınıf öğrencisi oluşturmaktadır. Okulların seçiminde çeşitlilik sağlamak adına sosyoekonomik durumları göz önünde tutulmuş, alt ve üst sosyoekonomik duruma sahip okullarda öğrenim gören öğrenciler belirlenmiştir. Sosyoekonomik düzeyin seçilme amacı, Suriyeli mülteci öğrencilerin yaşadıkları çevrede ve yetiştikleri aile ortamında karşılaştıkları Türkçe kelimeleri okurken kelime tanıma düzeyleri arasındaki farklılığı tespit etmektir. Araştırmaya katılan mülteci öğrencilerin 22'sinin kadın (\%68,75), 10'unun (\%31,25) erkek olduğu 
görülmektedir. Yaşa (ay) göre incelendiğinde araştırmaya katılan öğrencilerin 5 'inin $(\% 15,62) 72$ aydan küçük (69-71 ay), 27'sinin $(\% 84,38) 72$ ay ve üzeri ay aralığında olduğu görülmektedir. Öğrencilerin 16'sının (\%50) üst seviyede sosyoekonomik duruma sahip ilkokulda, 16'sının (\%50) alt seviyede sosyoekonomik duruma sahip ilkokulda olduğu görülmektedir. Okul öncesi eğitim alıpalmama değişkenine göre öğrencilerin $20^{\prime} \operatorname{sinin}(\% 62,5)$ okul öncesi eğitim aldığı, 12'sinin $(\% 37,5)$ okul öncesi eğitim almadığı görülmektedir.

\section{Veri Toplama Araçları}

Bu araştırmada Suriyeli mülteci öğrencilerin Türkçe kelimeleri tanıma düzeylerini belirlemek amacıyla veri toplama araçları olarak, Avşar Tuncay (2017) tarafından geliştirilen KTE ve Kelime Tanıma Çizelgesi kullanıımıştır.

KTE'de yer alan kelimeler Türkiye Cumhuriyeti Millî Eğitim Bakanlığı tarafından ilkokul birinci sınıflarda okutulması önerilen Türkçe, Hayat Bilgisi ve Matematik ders kitaplarında yer alan ve mülteci öğrencilerin günlük yaşantılarında sıklıkla karşılaştıkları kelimelerden seçilmiştir. Dik temel yazıyla hazırlanmış KTE'de, toplamda 800 kelimeden oluşan 40 tane kelime listesi bulunmaktadır. Envanterde 20 punto ile yazılan kelimelerden oluşan listeler, her biri bir sayfada yer alacak şekilde düzenlenmiştir. KTE'de yer alan kelimeler; yalın hâlde sunulmuş, öğrencilerin yaşına, bilgi düzeyine ve sınıf seviyesine uygun, hece sayısı, harf sayısına göre basitten karmaşığa doğru sıralanmış, sözcük çeşitliliğinin orantılı olduğu (benzer isim, sıfat, fiil kullanımı gibi...) 20 kelimeden oluşan listelerden meydana gelmiştir. Envanterde yer alan kelime listelerinin ses grupları ve liste sayısının gösteriliş biçimi Tablo 1'de yer almaktadır.

Tablo 1.

KTE'de Seviyelere Göre Hazırlanan Kelime Listelerinin Grup ve Sayılarının Dağılımı

\begin{tabular}{lll}
\hline \multicolumn{1}{c}{ Seviyeler } & Ses Grupları & KTE Liste SayıSI \\
\hline 1. Seviye & E, L, A, N & 1 \\
2. Seviye & I, T, O, B, U & 5 \\
3. Seviye & K, I, R, Ö, S, Ü & 5 \\
4. Seviye & M, D, Ş, Y, C, Z & 15 \\
5. Seviye & Ç, G, P, H & 8 \\
6. Seviye & F, V, G, J & 6 \\
\hline Toplam & & 40 \\
\hline
\end{tabular}

Veri toplama araçlarının diğeri olan Kelime Tanıma Çizelgesi, KTE'nin aksine öğrencilerin göremeyeceği şekilde sadece uygulayıııın kullanımı için tasarlanmış ölçme araçlarıdır. KTE'deki kelime listelerinin aynısının yer aldığı Kelime Tanıma Çizelgesinde, uygulayıcı öğrencilerin doğru/yanlış okuduğu kelimeleri kaydeder. Kelime Tanıma Çizelgesi'nde öğrencilerin doğru okudukları kelimeler "v" işaretiyle işaretlenip, hatalı okudukları kelimeler de okundukları gibi yazılır. Öğrencilerin yaptıkları okuma hataları, Roe ve Burns (2007) tarafından belirlenen tersine çevirme, ekleme yapma, çıkarma yapma, yanlış telaffuz, yerine koyma, tekrarlama ve son olarak öğretmenin doğruyu söylemesi şeklindedir. Çizelgede uygulayııının öğrencinin okuduğu doğru ve yanlış kelimeleri belirtebileceği doğru ve yanlış sayısı ile okuma sürelerini kaydedebileceği bir alan bulunmaktadır. Çizelgede öğrencilerin verdikleri cevaplar doğru/yanlış (1/0) olarak kodlansa da hataların birden fazla kod (tersine çevirme, ekleme yapma, çıkarma yapma, yanlış telaffuz, yerine koyma, tekrarlama ve öğretmenin doğruyu söylemesi) içermesi bakımından güvenirlik katsayıları hesaplanmış ve Cronbach Alpha güvenirlik katsayısına bakılmıştır. Buna göre KTE'nin tüm listelerinin Cronbach Alpha güvenirlik katsayısının .970 olduğu görülmektedir. Hesaplanan güvenirlik katsayısının .70 ve daha yüksek olması envanterin güvenirliği için genel olarak yeterli görülmektedir (Büyüköztürk, 2007). 


\section{Verilerin Toplanması}

Uygulamaya, sınıflarında mülteci öğrenci bulunan birinci sınıf öğretmenlerine çalışmanın amacı, kapsamı, öğrencilere nerede ve nasıl bir uygulama yapılacağı hakkında bilgiler verilerek başlanmıştır. Süreç, yeni ses grubu verildikçe mültecilere bir önceki ses grubundan elde edilen kelime listelerinin okunmasıyla devam etmiştir. Uygulamalar, kütüphane içerisinde yer alan boş bir çalışma odasında yapılmıştır. Uygulama sırasında mülteci öğrenci KTE'de yer alan kelime listelerini okurken, uygulayıcı aynı listelerin yer aldığı ama aynı zamanda işaretleme de yapabileceği Kelime Tanıma Çizelgesi'ni takip etmektedir. Çalışma odasında yer alan bir masada uygulayıcı ile öğrenci, öğrencinin uygulayıcının işaretlemelerini göremeyeceği şekilde karşı karşıya oturmuşlardır. Mülteci öğrencilerin özellikle okuma düzeyi zayıf olanların, bir yabancının yanında okumak istememesi çok doğaldır. Bunun için uygulayıcının öğrenciyi cesaretlendirmesi ve okumaya geçmeden önce öğrenciyle kısa kısa sohbet etmesi gerekmiştir. Öğrenciden kelimeleri tek tek sırayla okuması istenmiş, eğer kelimeyi okuması 10 saniyeden fazla sürdüyse sıradaki kelimeye geçmesi için öğrenci cesaretlendirilmiştir. Kelime Tanıma Çizelgesinde okuduğu kelimeler doğru/yanlış şeklinde kodlanmış ve toplam okuma süresi de kaydedilmiştir. Uygulayıcı çizelgeye doğru okunan her kelime için " $\mathrm{V}$ " işareti koymakta, hatalı okunan kelimeleri de okunduğu gibi yazmaktadır. Hatalı okunan kelimelerde ne tür okuma hatası yapıldığı değerlendirme aşamasında belirlenmektedir (Roe ve Burns, 2007). KTE uygulamasında uygulayıcının Kelime Tanıma Çizelgesinde izlediği adımlar şu şekilde sıralanmaktadır: 1. Başlangıç düzeyinde yer alan kelimeler zor da olsa öğrencilere okutulmakta, doğru okunan kelimelerin karşısına uygulayıcının çizelgesinde " $\sqrt{ }$ " işareti koymaktadır. 2. Öğrencinin hatalı okuduğu kelimeler uygulayıcının çizelgesinde okunduğu şekilde kaydedilmekte ve ödün verilmemektedir. 3. Öğrenci hatalı okuyup daha sonraki kelimeye geçmeden önce hatasını düzeltirse uygulayıcı çizelgesinde bunu belirterek doğru kabul etmekte ve bu kelime için ödün verilebilmektedir. 4. Öğrenci bir kelimeyi doğru okumadan önce birkaç defa hatalı okursa, hiçbir ödün verilmemektedir. 5. Öğrenci kelime okuma sırasında on saniyeden fazla bir süre bekliyorsa, uygulayıcı bir sonraki kelimeyi sunmakta ve ödün verilmemektedir. 6. Öğrencinin doğru okuduğu kelime sayısı kelime tanıma düzeyi puanına denktir (Silvaroli ve Wheelock, 2011; Woods ve Moe, 2011; Bader ve Pearce, 2013; Shanker ve Cockrum, 2014).

Hem A ilkokulunda hem de B ilkokulunda ilk seviye ses grubunun verilmeye başlamasından itibaren kelime listeleri sırasıyla 32 öğrenciye okutulmaya başlanmıştır. Toplamda 16 hafta, 288 saat süren uygulamalarda, 20 kelimeden oluşan 40 kelime listelerinde yer alan 800 kelime birinci sınıf mülteci öğrencilere okutulmuştur.

\section{Verilerin Analizi}

Öğrencilerin yaptıkları hatalara göre listede yer alan kelimelerin kaçını doğru, kaçını yanlış okudukları belirlenmiştir. "Kelime Tanıma Çizelgesi"nden alınan puanlar doğrultusunda doğru okunan kelime sayısı öğrencinin asıl puanını gösterecektir. Envanterin uygulanması sırasında eğer çocuk listede yer alan 20 kelimenin 19 tanesini eksiksiz okuyabilirse onun kelime tanıma düzeyi \%95 olacaktır. Bu da çocuğun "Bağımsız Okuma Düzeyi" nde olduğunu gösterir. "Öğretimsel Okuma Düzeyi" nde olan çocuk 20 kelimenin en fazla 3 tanesinde okuma hatası yapabilir ve bu da başarısının \%85 ve üzeri düzeyinde olduğunu gösterir. "Endişe Düzeyi" nde olan çocuk için okuyamadığı kelime sayısı oldukça fazladır ve bu da her 20 kelimenin 3 tanesinden daha fazla okuma hatası yapabileceği anlamına gelir. Bu çocuklar için kelime tanımada \%85'in altında bir başarı sağlandığını gösterir (Roe ve Burns, 2007). Aslında okuma envanterinde yer alan kelime listelerinin okutulması sırasında öğrenci listelerdeki kelimeleri öğretimsel ve bağımsız düzeyde okursa diğer ses grubuna geçiş yapabilirken, endişe düzeyinde yer alırsa bulunduğu ses grubundan bir alt seviyedeki grubun kelimelerini okuması istenmektedir. Fakat bu çalışmada kelimelerin okunma düzeyinin de araştırılmasından dolayı Türkçe kelimelerden hangi kelimenin mülteciler tarafından okunduğunun, hangi kelimenin okunamadığının karar verilmesi açısından yol göstereceği için listelerin tamamı öğrenciler tarafından okunmuştur. Öğrencilerin kelime tanıma listelerini okurken elde edilen verilerin çözümlenmesinde yaptığı okuma hatalarının kaydedildiği "Kelime Tanıma Çizelgesi” öğrencilerin doğru okuduğu her kelimeye 1 puan, 
yanlış okuduğu her kelimeye de 0 puan verilerek analiz edilmiş ve okuma düzeyi bu puana göre belirlenmiştir. Yapılan okuma hataları ise betimsel analiz kullanılarak yorumlanmıştır.

"Kelime Tanıma Çizelgesi"ne kaydedilen veriler bilgisayar ortamında "SPSS 22.0" paket programında analiz edilmiş, öğrenciler arasında çeşitli karşılaştırmalar yapılmıştır. Veriler tablo haline getirilmiş, sonuçlar 0,05 anlamlılık düzeyinde değerlendirilmiştir. Öğrencileri cinsiyete, yaşa (ay), sosyoekonomik düzeyine, okul öncesi eğitim alıp almama durumuna göre karşılaştırmada T-testi kullanılmıştır.

\section{Araştırmanın Etik Kurulu İzni}

$\mathrm{Bu}$ çalışma; Hacettepe Üniversitesi Etik Komisyonunun aşağıda yer alan bilgileri verilmiş toplantı kararı ile etik açıdan uygun bulunmuştur.

Tarih: 26. 07. 2016

Sayı: 35853172/433-2359

\section{Bulgular}

Bu bölümde, kelime tanımaya yönelik geliştirilen KTE'nin ilkokul birinci sınıf mülteci öğrencilerin Türkçe kelimeleri tanıma düzeylerini belirlemeye ilişkin bulgular yorumlanarak verilmiştir.

\section{KTE Tüm Kelime Tanıma Listelerine Ait Bulgular}

Aşağıda KTE uygulamasında tüm kelime listelerinde birinci sınıf mülteci öğrencilerin en çok doğru okudukları Türkçe kelimeler, bu kelimelerin türleri, yapılan hata sayısı ve ne tür hatalar yaptıkları Tablo 2'de yer almaktadır.

Tablo 2.

Mülteci Öğrencilerin KTE'de En Çok Doğru Okudukları Kelimelere Ait Bulgular

\begin{tabular}{cllll}
\hline Kelime Listeleri & Kelimeler & Kelime Türü & Hata Sayısı & Hata Türü \\
\hline 1. Seviye Kelime Listesi & El & İsim & 1 & Yerine Koyma \\
2. Seviye Kelime Listesi & At & İsim & 1 & Öğretmenin söylemesi \\
3. Seviye Kelime Listesi & Nar & İsim & - & Yerine Koyma \\
& Sel & İsim & - & - \\
& Sarı & İsim-Sıfat & - & - \\
4. Seviye Kelime Listesi & Dede & İsim & 1 & - \\
& Kuş & İsim & - & Ekleme Yapma \\
& Kitap & İsim & - & - \\
5. Seviye Kelime Listesi & Gül & İsim-Fiil & - & - \\
& Ev & İsim & - & - \\
6. Seviye Kelime Listesi & Yuva & İsim & - & - \\
& Sevgi & İsim & - & - \\
\hline
\end{tabular}

Tablo 2'ye göre KTE uygulanan öğrencilerin tüm kelime listelerine ait doğru okudukları kelimelerden elde edilen en dikkat çeken bulgu; 3., 5. ve 6. Seviye kelime listelerinin öğrencilerin tamamı tarafından hatasız okunmasıdır. Diğer listelerde en fazla 1 hata ya da 2 hata yapılmıştır. Bu kelimelerin öğrencilerin günlük yaşantılarında en sık duydukları kelimeler ve Karadağ’a göre (2013) öğrencilerin hedef kelime listelerinde yer alması gereken kelimelerden olduğu görülmektedir. Kelime türlerine göre bakılacak olunursa, en çok doğru okunan Türkçe kelimelerin türü isimdir. Kelime türü ile hata türü arasında ilişki kurulacak olunursa bu ilişki isim kelime türü ile yerine koyma hatası arasında kurulabilir. 
Aşağıda KTE uygulamasında tüm kelime listelerinde birinci sınıf mülteci öğrencilerin en çok yanlış okudukları Türkçe kelimeler, bu kelimelerin türleri, yapılan hata sayısı ve ne tür hatalar yaptıkları Tablo 3'te yer almaktadır.

Tablo 3.

Mülteci Öğrencilerin KTE'de En Çok Yanlış Okudukları Kelimelere Ait Bulgular

\begin{tabular}{lllll}
\hline Kelime Listeleri & Kelimeler & Kelime Türü & Hata Sayısı & Hata Türü \\
\hline 1. Seviye Kelime Listesi & Anneanne & İsim & 18 & $\begin{array}{l}\text { Çıkarma Yapma } \\
\text { Ekleme Yapma }\end{array}$ \\
2. Seviye Kelime Listesi & Atleti & İsim & 8 & Çıkarma Yapma \\
3. Seviye Kelime Listesi & Kask & İsim & 17 & Ekleme Yapma \\
4. Seviye Kelime Listesi & Sorumsuzluk & İsim & 15 & Çıkarma Yapma \\
5. Seviye Kelime Listesi & Müzayede & İsim & 9 & Çıkarma Yapma \\
6. Seviye Kelime Listesi & Misafirlik & İsim & 7 & Çıkarma Yapma \\
\hline
\end{tabular}

Tablo 3'e göre KTE uygulanan öğrencilerin tüm kelime listelerine ait doğru okudukları kelimelerden elde edilen en dikkat çeken bulgu; 1 . Seviye Kelime Listesinde yer alan "Anneanne" kelimesini çalışma grubunda yer alan öğrencilerin tamamına yakınının hatalı okumasıdır. Bu kelimenin okunuşunu "Anne" kelimesi ile karıştırarak çıkarma hatası yapmalarına ve bazı öğrencilerin de iki ünsüz harfin yan yana gelmesinde zorluk çektikleri için ekleme yapma ihtiyacı hissetmelerine bağlayabiliriz. Hatalı okunan kelimelerin yabancı kökenli olmaları da dikkati çeken bulgular arasındadır. Listelerde yer alan kelimelerin okunuşunda hataların en fazla çıkarma yapma hata türüyle yapıldığı bunu ekleme yapma hata türünün izlediği görülmektedir. Kelime türlerine göre bakılacak olunursa, en çok yanlış okunan kelimelerin türü isimdir. Kelime türü ile hata türü arasında ilişki kurulacak olunursa bu ilişki isim kelime türü ile çıkarma yapma hatası arasında kurulabilir.

\section{KTE Okunma Sürelerine Ait Bulgular}

Listelerin okunma sürelerine bakılacak olunursa en hızlı okunan listenin 4. Seviye Listelerinden 2. Liste; en yavaş okunan listenin de 4. Seviye Listelerinden 13. listenin olduğu görülmektedir. Listelerin okunma süreleri ve seviyeleri arasında bir ilişki kurulacak olunursa, listelerin seviyeleri ilerledikçe okunma hızları da aynı oranda artmaktadır. Bir diğer ifadeyle listeler ilerledikçe ve zorluk derecesi de aynı oranda arttıkça öğrencilerin okuması da hız kazanmıştır. En hızlı okunan liste 25 saniyede, en yavaş okunan liste de 2 dakikada okunmuştur.

\section{Mülteci Öğrencilerin KTE Kelime Listelerindeki Kelime Tanıma Düzeylerine Ait Bulgular}

$\mathrm{KTE}, 40$ tane kelime listesinden oluştuğu için öğrencilerden toplamda 800 kelime okuması istenmektedir. Bu 40 listenin ortalamasına bakılarak kelime tanıma düzeyleri tespit edilmeye çalışılmıştır. Birinci seviye kelime listesi sadece bir tane listeden oluştuğu için 19-20 kelimeyi doğru okuyan öğrenciler bağımsız düzeyde; 17-18 kelimeyi doğru okuyan öğrenciler öğretimsel düzeyde; 16 kelime ve aşağısını doğru okuyan öğrenciler de endişe düzeyindedir. İkinci ve üçüncü seviye kelime listeleri toplamda 5 listeden oluştuğu için öğrencilerden toplamda 100 kelime okuması istenmektedir. Bu 5 listenin ortalamasına bakılarak kelime tanıma düzeyleri tespit edilmeye çalışılmıştır. Dolayısıyla 100-95 kelime arasında doğru okuyan öğrenciler bağımsız düzeyde; 94-85 kelimeyi doğru okuyan öğrenciler öğretimsel düzeyde; 84 ve aşağısı kelimeyi doğru okuyan öğrenciler de endişe düzeyindedir. Dördüncü seviye kelime listeleri toplamda 15 listeden oluştuğu için öğrencilerden toplamda 300 kelime okuması istenmektedir. Bu 15 listenin ortalamasına bakılarak kelime tanıma düzeyleri tespit edilmeye çalışıımıştır. Kelimelerden 300-285 kelime arasında doğru okuyan öğrenciler bağımsız düzeyde; 284-255 kelimeyi doğru okuyan öğrenciler öğretimsel düzeyde; 254 ve aşağısı kelimeyi doğru okuyan öğrenciler de endişe düzeyindedir. Beşinci seviye kelime listeleri toplamda 8 listeden oluştuğu için öğrencilerden toplamda 160 kelime okuması istenmektedir. Bu 8 listenin ortalamasına bakılarak kelime tanıma düzeyleri tespit edilmeye çalışılmıştır. Kelimelerden 160-152 
kelime arasında doğru okuyan öğrenciler bağımsız düzeyde; 151-136 kelimeyi doğru okuyan öğrenciler öğretimsel düzeyde; 135 ve aşağısı kelimeyi doğru okuyan öğrenciler de endişe düzeyindedir. Altıncı seviye kelime listeleri toplamda 6 listeden oluştuğu için öğrencilerden toplamda 120 kelime okuması istenmektedir. Bu 6 listenin ortalamasına bakılarak kelime tanıma düzeyleri tespit edilmeye çalışılmıştır. Kelimelerden 120-114 kelime arasında doğru okuyan öğrenciler bağımsız düzeyde; 113-102 kelimeyi doğru okuyan öğrenciler öğretimsel düzeyde; 101 ve aşağısı kelimeyi doğru okuyan öğrenciler de endişe düzeyindedir. Aşağıda KTE'de yer alan kelime listelerini okuyan mülteci birinci sınıf öğrencilerinin kelime tanıma düzeylerini gösteren Tablo 4 yer almaktadır.

Tablo 4

Mülteci Öğrencilerin KTE Kelime Tanıma Düzeyleri Değerleri

\begin{tabular}{|c|c|c|c|c|c|c|c|c|c|c|c|c|}
\hline \multirow[t]{2}{*}{$\begin{array}{l}\text { Kelime Tanıma } \\
\text { Düzeyleri }\end{array}$} & \multicolumn{2}{|c|}{$\begin{array}{l}\text { 1. Seviye } \\
\text { Kelime } \\
\text { Listesi }\end{array}$} & \multicolumn{2}{|c|}{$\begin{array}{l}\text { 2. Seviye } \\
\text { Kelime } \\
\text { Listesi }\end{array}$} & \multicolumn{2}{|c|}{$\begin{array}{l}\text { 3. Seviye } \\
\text { Kelime } \\
\text { Listesi }\end{array}$} & \multicolumn{2}{|c|}{$\begin{array}{l}\text { 4. Seviye } \\
\text { Kelime } \\
\text { Listesi }\end{array}$} & \multicolumn{2}{|c|}{$\begin{array}{l}\text { 5. Seviye } \\
\text { Kelime } \\
\text { Listesi }\end{array}$} & \multicolumn{2}{|c|}{$\begin{array}{l}\text { 6. Seviye } \\
\text { Kelime } \\
\text { Listesi }\end{array}$} \\
\hline & $\mathrm{N}$ & $\%$ & $\mathrm{~N}$ & $\%$ & $\mathrm{~N}$ & $\%$ & $\mathrm{~N}$ & $\%$ & $\mathrm{~N}$ & $\%$ & $\mathrm{~N}$ & $\%$ \\
\hline Bağımsız Düzey & - & - & - & - & - & - & 2 & 6,3 & 6 & 18,8 & 14 & 43,8 \\
\hline $\begin{array}{l}\text { Öğretimsel } \\
\text { Düzey }\end{array}$ & 4 & 12,5 & 5 & 15,6 & 4 & 12,5 & 9 & 28,1 & 20 & 62,5 & 18 & 56,3 \\
\hline Endişe Düzeyi & 28 & 87,5 & 27 & 84,4 & 28 & 87,5 & 21 & 65,6 & 6 & 18,8 & - & - \\
\hline Toplam & 32 & 100 & 32 & 100 & 32 & 100 & 32 & 100 & 32 & 100 & 32 & 100 \\
\hline
\end{tabular}

Tablo 4'e göre ilk üç seviye kelime listelerinde bağımsız düzeyde hiç öğrenci bulunmamakta; dördüncü seviye kelime listelerinde 2, beşinci seviye kelime listelerinde 6 ve en son altıncı seviye kelime listelerinde de sayının 14 olduğu görülmektedir. Öğretimsel düzeyde yer alan öğrenci sayısı birinci seviye kelime listelerinde 4, ikinci seviye kelime listelerinde 5, üçüncü seviye kelime listelerinde 4, dördüncü seviye kelime listelerinde 9, beşinci seviye kelime listelerinde 20 ve son olarak altıncı seviye kelime listelerinde 18 olduğu görülmektedir. Aynı şekilde endişe düzeyine bakılacak olunursa sayının en fazla birinci ve üçüncü seviye kelime listelerinde olduğu görülmektedir ve bu sayı $28^{\prime}$ dir. İkinci seviye kelime listelerinde 27 , dördüncü seviye kelime listelerinde 21 , beşinci seviye kelime listelerinde 6 ve son olarak altıncı seviye kelime listelerinde endişe düzeyinde öğrencinin olmadığı görülmektedir. Buna göre endişe düzeyinde yer alan öğrenci sayısı kelime listeleri ilerledikçe azalmakta; bağımsız düzeyde yer alan öğrenci sayısı kelime listeleri okundukça artmaktadır. Bu bulgu, öğrencinin öğretmen ya da başka bir yetişkinin yardımına ihtiyaç duymadan düzeyine uygun materyalleri okuması ve anlamasını ifade etmektedir.

\section{KTE Uygulanan Mülteci Öğrencilerin Kelime Tanıma Düzeylerinin Demografik Özelliklerine Ait Bulgular}

KTE uygulanan mülteci öğrencilerin öncelikle normal dağııım gösterip göstermediğini tespit etmek amacıyla çarpıklık, basıklık, aritmetik ortalama, ortanca ve mod gibi betimsel istatistiklere bakılmıştır. Listelerde yer alan kelime sayıları birbiriyle aynı olmadığından listeler arasında karşılaştırmayı kolaylaştırmak için en yüksek puana göre puanlar yeniden ölçeklendirilmiştir. Buna göre seviyeler arasında en fazla kelime 300 kelime ile 4. Seviye Kelime Listelerinde bulunmaktadır. 1. Seviye Kelime Listesi toplamda 20 kelimeden oluştuğu için 15 ile; 2. ve 3. Seviye Kelime Listeleri toplamda 100 kelimeden oluştuğu için 3 ile; 5. Seviye Kelime Listeleri 160 kelimeden oluştuğu için 1.87 ile ve 6 . Seviye Kelime Listeleri 120 kelimeden oluştuğu için 2.5 ile çarpılmıştır. Listelerin aritmetik ortalamaları, ortanca ve modları karşılaştırıldığında normalden aşırı uzaklaşmadığı, birbirine yakın değerler aldığı görülmektedir. Ancak bu üç istatistik için belirlenmiş bir ölçüt olmadığından çarpıklığa ve basıklığa bakılmasının daha uygun olduğu söylenebilir. Çarpıklık katsayısı basıklık katsayısına göre daha kritik sonuçlar verir. Çarpıkık katsayısının -1 ile +1 arasında değer alması puanların normal dağılımdan önemli bir sapma göstermediği şeklinde yorumlanabilir. Dolayısıyla tüm kelime listelerinde yer alan değerlere göre çarpıklık değerinin -1 'den uzaklaştığı görülmüştür. 
Dolayısıyla tüm verilerin normal dağılım gösterdiği düşünülmüştür. Buna göre verilerin normal dağılım gösterdiği durumlarda uygulanan parametrik testlere ait bulgular aşağıda verilmiştir.

KTE'de yer alan kelime listelerini okuyan mülteci öğrencilerin kelime tanıma düzeylerine ilişkin cinsiyet değişkenine ait T-testi sonuçları Tablo 5'te sunulmuştur.

Tablo 5.

KTE Uygulanan Mülteci Öğrencilerin Kelime Tanıma Düzeylerinin Cinsiyet Değişkenine Göre T-Testi Sonuçları

\begin{tabular}{|c|c|c|c|c|c|c|c|}
\hline $\begin{array}{l}\text { Kelime Tanıma } \\
\text { Düzeyleri }\end{array}$ & Cinsiyet & $N$ & Ortalama & SS & sd & $\mathrm{t}$ & $\mathrm{p}$ \\
\hline \multirow{2}{*}{ 1. Seviye Kelime Listesi } & Kadın & 22 & 10,22 & ,86 & \multirow{2}{*}{30} & \multirow{2}{*}{,- 626} & \multirow{2}{*}{,536 } \\
\hline & Erkek & 10 & 11,30 & 1,69 & & & \\
\hline \multirow{2}{*}{ 2. Seviye Kelime Listesi } & Kadın & 22 & 64,45 & 3,22 & \multirow{2}{*}{30} & \multirow{2}{*}{$-1,967$} & \multirow{2}{*}{,058 } \\
\hline & Erkek & 10 & 75,70 & 4,65 & & & \\
\hline \multirow{2}{*}{ 3. Seviye Kelime Listesi } & Kadın & 22 & 71,31 & 2,11 & \multirow{2}{*}{30} & \multirow{2}{*}{$-2,055$} & \multirow{2}{*}{,049 } \\
\hline & Erkek & 10 & 79,10 & 3,14 & & & \\
\hline \multirow{2}{*}{ 4. Seviye Kelime Listesi } & Kadın & 22 & 229,81 & 5,85 & \multirow{2}{*}{30} & \multirow{2}{*}{$-2,120$} & \multirow{2}{*}{042} \\
\hline & Erkek & 10 & 254,70 & 11,80 & & & \\
\hline \multirow{2}{*}{ 5. Seviye Kelime Listesi } & Kadın & 22 & 143,90 & 1,77 & \multirow{2}{*}{30} & \multirow{2}{*}{,- 371} & \multirow{2}{*}{,713 } \\
\hline & Erkek & 10 & 145,20 & 3,40 & & & \\
\hline \multirow{2}{*}{ 6. Seviye Kelime Listesi } & Kadın & 22 & 113,04 & 1,08 & \multirow{2}{*}{30} & \multirow{2}{*}{ 708 } & \multirow{2}{*}{, 484 } \\
\hline & Erkek & 10 & 111,70 & 1,49 & & & \\
\hline
\end{tabular}

Tablo 5'e göre kelime listelerinin 1. Seviye Kelime Listelerinde $\left(t_{(30)}=-.626, p>.05\right) ; 5$. Seviye Kelime Listelerinde $\left(t_{(30)}=-, 371 p>.05\right)$ ve 6 . Seviye Kelime Listelerinde $\left(t_{(30)}=, 708 p>.05\right)$ mülteci birinci sınıf öğrencilerinin kelime tanıma düzeylerine ilişkin puanlarında cinsiyet değişkenine göre istatistiksel olarak anlamlı bir fark olmadığı hesaplanmıştır. 2. Seviye Kelime Listelerinde $\left(t_{(30)}=-\right.$ $1.967, \mathrm{p}<.05) ; 3$. Seviye Kelime Listelerinde $\left(t_{(30)}=-2.055, \mathrm{p}<.05\right) ; 4$. Seviye Kelime Listelerinde $\left(t_{(30)}=\right.$ -2.120, p<.05) mülteci birinci sınıf öğrencilerinin kelime tanıma düzeylerine ilişkin puanlarında cinsiyet değişkenine göre istatistiksel olarak anlamlı bir farklılık olduğu saptanmıştır. Elde edilen fark erkek öğrenciler lehinedir. Bu bulgu erkek mülteci öğrencilerin kız mülteci öğrencilere göre okuma düzeylerinin daha iyi olduğu anlamına gelmektedir.

KTE'de yer alan kelime listelerini okuyan mülteci öğrencilerin kelime tanıma düzeylerine ilişkin yaş değişkenine ait T-testi sonuçları Tablo 6'de sunulmuştur.

Tablo 6.

KTE Uygulanan Mülteci Öğrencilerin Kelime Tanıma Düzeylerinin Yaş Değişkenine Göre T-Testi Sonuçları

\begin{tabular}{|c|c|c|c|c|c|c|c|}
\hline $\begin{array}{l}\text { Kelime Tanıma } \\
\text { Düzeyleri }\end{array}$ & Yaş (ay) & $\mathrm{N}$ & Ortalama & ss & sd & $\mathrm{t}$ & $p$ \\
\hline \multirow{2}{*}{ 1. Seviye Kelime Listesi } & 72 ay altı & 5 & 9,60 & 6,26 & \multirow{2}{*}{30} & \multirow{2}{*}{,- 520} & \multirow{2}{*}{,607 } \\
\hline & 72 ay ve üzeri & 27 & 10,74 & 4,16 & & & \\
\hline \multirow{2}{*}{ 2. Seviye Kelime Listesi } & 72 ay altı & 5 & 68,40 & 17,24 & \multirow{2}{*}{30} & \multirow{2}{*}{,066 } & \multirow{2}{*}{ 948 } \\
\hline & 72 ay ve üzeri & 27 & 67,88 & 15,71 & & & \\
\hline \multirow{2}{*}{ 3. Seviye Kelime Listesi } & 72 ay altı & 5 & 71,60 & 11,52 & \multirow{2}{*}{30} & \multirow{2}{*}{,- 496} & \multirow{2}{*}{,624 } \\
\hline & 72 ay ve üzeri & 27 & 74,14 & 10,40 & & & \\
\hline \multirow{2}{*}{ 4. Seviye Kelime Listesi } & 72 ay altı & 5 & 237,20 & 34,14 & \multirow{2}{*}{30} & \multirow{2}{*}{,- 029} & \multirow{2}{*}{977} \\
\hline & 72 ay ve üzeri & 27 & 237,66 & 32,81 & & & \\
\hline \multirow{2}{*}{ 5. Seviye Kelime Listesi } & 72 ay altı & 5 & 145,80 & 3,89 & \multirow{2}{*}{30} & \multirow{2}{*}{ 397 } & \multirow{2}{*}{,694 } \\
\hline & 72 ay ve üzeri & 27 & 144,03 & 9,67 & & & \\
\hline 6. Seviye Kelime Listesi & 72 ay altı & 5 & 115,00 & 3,08 & 30 & 1,177 & 249, \\
\hline
\end{tabular}


Tablo 6'ya göre kelime listelerinin 1. Seviye Kelime Listelerinde $\left(t_{(30)}=-.520, p>.05\right) ; 2$. Seviye Kelime Listelerinde $\left(t_{(30)}=, 066 p>.05\right) ; 3$. Seviye Kelime Listelerinde $\left(t_{(30)}=-, 496 p>.05\right) ; 4$. Seviye Kelime Listelerinde $\left(t_{(30)}=-.029, p>.05\right) ; 5$. Seviye Kelime Listelerinde $\left(t_{(30)}=, 397 p>.05\right)$ ve 6 . Seviye Kelime Listelerinde $\left(t_{(30)}=1,177 p>.05\right)$ mülteci birinci sını öğrencilerinin kelime tanıma düzeylerine ilişkin puanlarında yaş değişkenine göre istatistiksel olarak anlamlı bir fark olmadığı hesaplanmıştır. Bu bulgu mülteci öğrencilerin okuma düzeylerine yaş değişkeninin etki etmediğini göstermektedir. KTE'de yer alan kelime listelerini okuyan mülteci öğrencilerin kelime tanıma düzeylerine ilişkin sosyoekonomik durum (SED) değişkenine ait T-testi sonuçları Tablo 7'de sunulmuştur.

Tablo 7.

KTE Uygulanan Mülteci Öğrencilerin Kelime Tanıma Düzeylerinin Sosyoekonomik Durum (SED) Değişkenine Göre T-Testi Sonuçları

\begin{tabular}{llllllll}
\hline $\begin{array}{l}\text { Kelime Tanıma } \\
\text { Düzeyleri }\end{array}$ & SED & $\mathrm{N}$ & Ortalama & ss & sd & t & $\mathrm{p}$ \\
\hline \multirow{2}{*}{ 1. Seviye Kelime Listesi } & Üst & 16 & 13,06 & 3,87 & \multirow{2}{*}{30} & 3,808 &, 001 \\
& Alt & 16 & 8,06 & 3,54 & & & \\
2. Seviye Kelime Listesi & Üst & 16 & 75,81 & 9,28 & 30 & 3,236 &, 003 \\
& Alt & 16 & 60,12 & 17,02 & & & \\
3. Seviye Kelime Listesi & Üst & 16 & 78,68 & 7,36 & 30 & 3,004 &, 005 \\
& Alt & 16 & 68,81 & 10,89 & & & \\
4. Seviye Kelime Listesi & Üst & 16 & 244,37 & 35,73 & 30 & 1,190 &, 243 \\
& Alt & 16 & 230,81 & 28,32 & & & \\
5. Seviye Kelime Listesi & Üst & 16 & 148,37 & 7,36 & 30 & 2,828 &, 008 \\
& Alt & 16 & 140,25 & 8,82 & & & \\
6. Seviye Kelime Listesi & Üst & 16 & 113,87 & 5,21 & 30 & 1,456 &, 156 \\
& Alt & 16 & 111,37 & 4,47 & & & \\
\hline
\end{tabular}

Tablo 7'ye göre kelime listelerinin 4. Seviye Kelime Listelerinde $\left(t_{(30)}=1,190, p>.05\right)$ ve 6 . Seviye Kelime Listelerinde $\left(t_{(30)}=1,456\right.$ p $\left.>.05\right)$ mülteci birinci sınıf öğrencilerinin kelime tanıma düzeylerine ilişkin puanlarında sosyoekonomik durum değişkenine göre istatistiksel olarak anlamlı bir fark olmadığı hesaplanmıştır. 1. Seviye Kelime Listelerinde $\left(t_{(30)}=3.808, p<.05\right) ; 2$. Seviye Kelime Listelerinde $\left(t_{(30)}=3.236, p<.05\right) ; 3$. Seviye Kelime Listelerinde $\left(t_{(30)}=3.004, p<.05\right)$ ve 5 . Seviye Kelime Listelerinde $\left(t_{(30)}=2,828, p>.05\right)$ mülteci birinci sınıf öğrencilerinin kelime tanıma düzeylerine ilişkin puanlarında sosyoekonomik durum değişkenine göre istatistiksel olarak anlamlı bir farklılık olduğu saptanmıştır. Elde edilen fark üst sosyoekonomik duruma sahip mülteci öğrenciler lehinedir. $\mathrm{Bu}$ bulgu, sosyoekonomik düzeyi iyi olan mülteci öğrencilerin kelime tanıma düzeylerinin sosyoekonomik düzeyi iyi olmayan mülteci öğrencilere göre daha iyi olduğunu göstermektedir.

KTE'de yer alan kelime listelerini okuyan mülteci öğrencilerin kelime tanıma düzeylerine ilişkin okul öncesi eğitim alıp almama değişkenine ait T-testi sonuçları Tablo 8'de sunulmuştur.

Tablo 8.

KTE Uygulanan Mülteci Öğrencilerin Kelime Tanıma Düzeylerinin Okul Öncesi Eğitim Alıp Almama Değişkenine Göre T-Testi Sonuçları

\begin{tabular}{llllllll}
\hline $\begin{array}{l}\text { Kelime Tanıma } \\
\text { Düzeyleri }\end{array}$ & $\begin{array}{l}\text { Okul Öncesi } \\
\text { Eğitim }\end{array}$ & $\mathrm{N}$ & Ortalama & ss & sd & $\mathrm{t}$ & $\mathrm{p}$ \\
\hline 1. Seviye Kelime Listesi & Almış & 20 & 12,80 & 3,72 & 30 & 4,806 &, 000 \\
2. Seviye Kelime Listesi & Almamış & 12 & 6,83 & 2,75 & & 30,030 &, 005
\end{tabular}




\begin{tabular}{|c|c|c|c|c|c|c|c|}
\hline \multirow{3}{*}{ 3. Seviye Kelime Listesi } & Almamış & 12 & 58,33 & 18,97 & \multirow{3}{*}{30} & \multirow{3}{*}{2,684} & \multirow{3}{*}{,012 } \\
\hline & Almış & 20 & 77,25 & 8,23 & & & \\
\hline & Almamış & 12 & 67,91 & 11,41 & & & \\
\hline \multirow[b]{2}{*}{ 4. Seviye Kelime Listesi } & Almış & 20 & 243,20 & 32,56 & \multirow[b]{2}{*}{30} & \multirow[b]{2}{*}{1,274} & \multirow[b]{2}{*}{,212 } \\
\hline & Almamış & 12 & 228,25 & 31,36 & & & \\
\hline \multirow{2}{*}{ 5. Seviye Kelime Listesi } & Almış & 20 & 147,55 & 8,10 & \multirow{2}{*}{30} & \multirow{2}{*}{2,933} & \multirow{2}{*}{ 006 } \\
\hline & Almamış & 12 & 138,91 & 7,99 & & & \\
\hline \multirow{2}{*}{ 6. Seviye Kelime Listesi } & Almış & 20 & 113,65 & 4,80 & \multirow{2}{*}{30} & \multirow{2}{*}{1,548} & \multirow{2}{*}{ 132 } \\
\hline & Almamış & 12 & 110,91 & 4,88 & & & \\
\hline
\end{tabular}

Tablo 8'e göre kelime listelerinin 4. Seviye Kelime Listelerinde $\left(t_{(30)}=1,274, p>.05\right)$ ve 6 . Seviye Kelime Listelerinde $\left(t_{(30)}=1,548\right.$ p >.05) mülteci birinci sınıf öğrencilerinin kelime tanıma düzeylerine ilişkin puanlarında okul öncesi eğitim alıp almama değişkenine göre istatistiksel olarak anlamlı bir fark olmadığı hesaplanmıştır. 1. Seviye Kelime Listelerinde $\left(t_{(30)}=4.806, p<.05\right) ; 2$. Seviye Kelime Listelerinde $\left(t_{(30)}=3.030, p<.05\right)$; 3. Seviye Kelime Listelerinde $\left(t_{(30)}=2.684, p<.05\right)$ ve 5 . Seviye Kelime Listelerinde $\left(t_{(30)}=2,933, p>.05\right)$ mülteci birinci sınıf öğrencilerinin kelime tanıma düzeylerine ilişkin puanlarında okul öncesi eğitim alıp almama değişkenine göre istatistiksel olarak anlamlı bir farklılık olduğu saptanmıştır. Elde edilen fark okul öncesi eğitim almış mülteci öğrenciler lehinedir. Bu bulgu, okul öncesi eğitim almış mülteci öğrencilerin kelime tanıma düzeyleri, okul öncesi eğitim almamış mülteci öğrencilere göre daha iyi olduğunu göstermektedir.

\section{Tartışma, Sonuç ve Öneriler}

Bu çalışmada sürece dayalı olarak hazırlanan ve değerlendirilen, iyi bir ölçme aracı niteliklerini taşıyan ve kelime tanımaya yönelik geliştirilen KTE'nin ilkokul birinci sınıf mülteci çocukların Türkçe kelimeleri tanıma düzeylerini belirlemede etkililiğini ortaya koymak amaçlanmıştır. Buna göre KTE uygulanan birinci sınıf mülteci öğrencilerin en çok doğru okudukları kelimeler, en çok yanlış okudukları kelimeler, okuma süreleri ve demografik bilgilerine göre kelime tanıma düzeyi puanları karşılaştırmalarına ait bulgulardan elde edilen sonuçlar şu şekilde sıralanmışır: Bu araştırmada en çok doğru okunan kelimelerin büyük çoğunluğunun isimlerden oluştuğu görülmektedir. Bazı araştırmacılar (Çıplak, 2005; Temur, 2006; Karahan, 2007; Yersüren, 2009 Çetinkaya, 2011) kelime türlerini inceledikleri çalışmalarında, isimlerin diğer türlere oranla öğrenciler tarafından daha fazla kullanıldığını belirlemişlerdir. Bu çalışmada en çok doğru okunan kelimeler arasında yer alan "Dede" kelimesi tekrarlı seslerden oluşması ve erken çocukluk dönemlerinde çocukların sık sık kullandığı kelimeler arasında olması bakımından dikkat çekicidir. Yine aynı şekilde "Sarı" gibi renk ismi; "El" gibi organ ismi; "At", "Kuş" gibi hayvan isimleri; "Nar" gibi meyve ismi; "Gül” gibi bitki ismi; "Sel" gibi afet ismi de mülteci çocukların en çok doğru okudukları kelimeler arasındadır. Burada doğru okunan kelimelerin hemen hepsinin tek heceli oluşu dikkat çekicidir. Bir diğer dikkat çeken bulgu da "Kitap" gibi okulu çağrıştıran, "Sevgi" gibi duygu ifade şeklini yansıtan; "Yuva", "Ev" gibi mülteci öğrencilerin eksikliğini hissettiği mekânların en çok doğru okudukları kelimeler arasında yer almasıdır. Karadağ’a göre (2013), öğrencilerin yazılı anlatımlarından elde ettiği hedef kelime listesine göre "Sevgi", "Ev", "El" kelimeleri ilköğretim öğrencilerinin öğrenmeleri gereken kelimeler arasında yer almaktadır.

Mülteci öğrenciler tarafından en çok yanlış okunan kelimeler arasında Türkçe kökenli (Annene, sorumsuzluk, misafirlik) kelimelerin dışında Fransızca (atleti, kask) ve Arapça (müzayede) kökenli kelimelerin yer aldığı görülmektedir. Bu bulgu, ana dillerinin Arapça olduğu düşünüldüğünde en dikkat çeken bulgulardan biri olduğu görülmektedir. Aynı şekilde Yalçın (2005) da çalışmasında Türkçe kökenli kelimelerin dışında en çok doğru okunan kelimelerin Arapça, Farsça ve Fransızca kökenli kelimeler olduğunu belirtmiştir. Genellikle en çok yanlış okunan kelimelerde öğrencilerin çıkarma yaparak kelimeyi hatalı okudukları görülmüştür. Bir diğer bulgu da soyut kelimelerin somut kelimelere oranla öğrenciler tarafından daha hatalı okunduklarıdır. Aköz ve Toptaş (2009) çalışmalarında, soyut anlam içeren sözcüklerin öğrenciler tarafından yeterince tanınmadıklarını ortaya koymuşlardır. Ayrıca Genç (2010), çalışmasında özellikle 1, 2 ve 3. sınıf öğrencilerinin 
kelimeleri anlamlandırmaları ve okuduklarını daha iyi anlamaları için ders kitaplarında somut sözcüklerin kullanılması gerektiğini vurgulamaktadır.

KTE kelime listelerinin okunma süreleri arasında seviyeler ilerledikçe okunma hızlarında da gelişme olduğu sonucuna ulaşılmıştır. Bir diğer ifadeyle listeler ilerledikçe ve çoğaldıkça mülteci öğrencilerin okuması da hız kazanmıştır. Bu bulguyu destekler nitelikte bir bulgu da endişe düzeyinde yer alan öğrenci sayısı kelime listeleri ilerledikçe azalmakta; bağımsız düzeyde yer alan öğrenci sayısı da artmaktadır. Bağımsız düzeyde okuma düzeyine sahip olan bir öğrenci öğretmen ya da başka bir yetişkinin yardımına intiyaç duymadan düzeyine uygun materyalleri okur ve anlar. Listede yer alan kelimeler endişe düzeyinde olan bir öğrenci için okunması zor bulunurken, bağımsız ve öğretimsel düzeyde yer alan bir öğrenci için okunması kolay olabilir. Çünkü öğrencilerin kelime tanıma düzeyleri bireysel farklılıklar göstermektedir. Yapılan araştırmalara göre öğrenciler günde ortalama 8; yılda yaklaşık olarak 2000-3000 kelime öğrenebilmektedirler (Stahl ve Nagy, 2006; Baker, Simmons ve Kame'enui, 1995). Bu sonuçlardan da yola çıkarak öğrencilerin öğrendiği sözcük sayısının bireyden bireye büyük ölçüde farklıık gösterdiği görülmektedir. Bazı öğrenciler 8 kelime öğrenirken, bazıları yalnızca 1 kelime öğrenebilmektedir. Bu nedenle özellikle mülteci öğrencilerin bildikleri kelime sayısı arasında büyük farklılıklar olabilmektedir. Bu farklılık okul hayatı boyunca devam etmekte hatta artış gösterebilmektedir. Okuma düzeyi endişe düzeyinde olan mülteci öğrencilere kelime edinimi için çeşitli kaynaklar önerilebilir. Bu kaynaklardan en etkili olanlarından biri medya araçlarıdır. Short'un (2013) Amerika Birleşik Devletleri'ndeki tüketiciler üzerine yaptığı rapora göre; öğrencilerin kelime öğreniminde temel aldıkları kaynaklar medya araçlarıdır. Özellikle çocuk kuşağı programlarında mülteci öğrencilerin kelime edinimini sağlayacak kelimelerin sıklıkla kullanımı sağlanabilir. Endişe düzeyinde okuma yapan öğrencilerin zayıf kelime bilgilerinin gelişimi için yapılabilecekler arasında; çocuk edebiyatında yer alan kitaplardan çocukların ilgisini çekecek nitelikteki kitapların, sesli kitap okuma çalışmaları kapsamında sınıf içinde öğretmen tarafından okunmasının katkı sağlayacağı düşünülmektedir (Santoro, Chard, Howad ve Baker, 2008). Okuma düzeyi endişe ya da öğretimsel düzeyde olan öğrencilerin kelime ediniminde yararlanılan kaynaklardan biri de metinlerdir. Öğretilecek kelimenin farklı anlamları, özellikleri, cümle içinde kullanımına yönelik çalışmalar yapılmalıdır. Özellikle endişe düzeyinde olan mülteci öğrenciler için yeni öğrenilen kelimeyle ne kadar sık karşılaşılırsa öğrenilme oranı da bir o kadar kolay olacaktır. Güneş (2013) bir kelimenin öğrencinin zihninde depolanması için o kelimeyle en az 12 defa yazılı veya sözlü olarak karşılaşması ve tanıma işlemlerini yapması gerektiğini söyler. Öğrencilerin kelime öğrenmesi için kullanılan araçlardan biri de kelime tanıma listeleridir. Öğrencilerin kelime tanıma listelerinde gösterdikleri başarı, kelime bilgisinin artmasında etken bir faktördür. Öğrenciler kelime listelerini okudukları sırada karşılaştıkları yeni kelimelerin anlamlarına ilişkin bilgiler edinebilmekte, böylece kavram ve kelime bilgilerini genişletebilmektedirler. Walpole ve McKenna (2006) bir araştırmalarında öğrencilerin kelime tanıma düzeylerine göre uygulanacak kelime listeleri sonucunda okuma düzeylerini iyileştirmek adına izlenecek basamakları gösteren bir tablo oluşturmuşlardır. Buna göre zayıf kelime tanıma düzeyinde yer alan öğrencilere fonolojik farkındalığı arttıran çalışmalar ile tekrarlı okuma çalışmaları içeren alıştırmalar yaptırmanın yararlı olacağını belirtmişlerdir. İyi kelime tanıma düzeyinde olan öğrencilere ise dikte çalışmaları ve sesli okuma çalışmaları yaptırmanın gerekli olduğunu vurgulamışlardır.

KTE uygulanan ilkokul birinci sınıf mülteci öğrencilerin cinsiyet değişkenine göre kelime tanıma düzeyi puanları karşılaştırıldığında üç seviye kelime listelerinde fark çıkmazken diğer üç seviye kelime listelerinde fark çıkmıştır. Sadece bazı seviyelerde fark çıkması kadın-erkek öğrencilerin kelime tanıma düzeyi puanları arasında fark olduğu anlamına gelmemelidir. Bu durum, bu listelerin uygulandığı zaman erkek öğrencilerin daha başarılı olmasıyla açıklanabilir. Diğer seviyelerdeki kelime listelerinde, birinci sınıf mülteci öğrencilerin kelime tanıma düzeyi puanlarına göre cinsiyetleri arasında anlamlı bir farklılık olmamasına rağmen, erkek öğrencilerin kelime tanıma düzeyi puanlarının daha yüksek olduğu dikkat çekmektedir. Benzer bir çalışma Batur (2006) tarafından kadın ve erkek öğrencilerin kelimeleri bilme başarıları üzerine yapılmıştır. Öğrencilerin kelime bilme başarıları hemen hemen birbirine yakın çıkmıştır. Araştırma sonunda cinsiyet ile kelime kazanımı arasında doğrudan bir ilişki bulunmamıştır. Konur-Ergene (2011) çalışmasında öğrencilerin kelimeleri öğrenme bakımından 
cinsiyet etkili değildir sonucuna ulaşmıştır. Özkan (2012) çalışmasında sözcük kazanımında ve bunları iç sözlüklerine alabilmeleri sürecinde kızların erkeklere göre daha etkin olduğu sonucuna ulaşmıştır.

KTE uygulanan ilkokul birinci sınıf mülteci öğrencilerin yaş değişkenine göre kelime tanıma düzeyi puanları karşılaştırıldığında anlamlı bir fark olmadığı görülmektedir. KTE'de 72 ay ve üzeri öğrencilerin kelime tanıma düzeyi puanları, 72 ay altı öğrencilerin kelime tanıma düzeyi puanlarına göre biraz daha yüksektir. Çıplak (2005) öğrencilerin hem biyolojik hem de eğitim yaşı yükseldikçe kelime çeşitliliğinin de doğal olarak arttığını tespit etmiştir. Cesur (2005) çalışmasında bu çalışmadan farklı olarak öğrencilerin yaş düzeylerine göre kullandığı kelimelerde farklılıklar bulmuştur. Öğrencilerin ileride neler yaşamak istediklerini anlattıkları kompozisyon çalışmalarında aktif kelime düzeylerini belirlemenin mümkün olduğu görülmüştür. Kılıç’ın (2014) “ilkokul birinci sınıfa devam eden 60-66-72 aylık öğrencilerin dil becerileri"ni incelediği çalışmasında 60-66-72 aylıklar yaş gruplarına göre anlamlı düzeyde farklılaşmaktadır. Analizlerden elde edilen sonuçlarda 72 ay ve üzeri öğrencilerin dil becerileri ile 60-66 aylık ve 66-72 aylık öğrencilerin dil becerileri arasındaki anlamlı farklıı̆ın 72 ay ve üzeri öğrencilerin lehine olduğu görülmüştür. 60-66 aylık ve 66-72 aylık öğrencilerin okuma becerilerine ait maddelerden aldıkları puanların bazen düzeyinde; 72 ay ve üzeri öğrencilerin okuma becerilerine ait maddelerden aldıkları puanların sıklıkla düzeyinde olduğu bulgusunu elde etmiştir. Bu bağlamda araştırmadan elde edilen bulgular, alanyazında geçen yaş (ay) arttıkça kelime tanıma düzeyinin de artacağına yönelik hipotezleri desteklememektedir.

KTE uygulanan ilkokul birinci sınıf mülteci öğrencilerin sosyoekonomik durum değişkenine göre kelime tanıma düzeyi puanları karşılaştırıldığında 4. ve 6. Seviye kelime listelerinde fark bulunmazken, 1., 2., 3. ve 5. Seviye kelime listelerinde fark bulunmuştur. KTE'de yer alan bazı ses gruplarından oluşturulan kelime listelerinin okunmasındaki farklılıklar, sosyoekonomik durumlarına göre anlamlı bulunmasa da üst sosyoekonomik duruma sahip öğrencilerin alt sosyoekonomik duruma sahip öğrencilerin kelime tanıma düzeyi puanlarından daha yüksek puana sahip olduğu sonucuna ulaşıımıştır. Ocak'a göre (2007) ailenin sosyo-kültürel ve ekonomik durumu, öğrencinin okul hayatını, ilk okuma yazma çalışmalarını, ilk okuma yazma sürecini etkileyen önemli bir faktördür. Sosyoekonomik düzey yükseldikçe, ebeveynlerin çocuklarına karşı tutumu olumlu yönde değişmekle birlikte çocuğa kazandıracakları okuma yazma deneyimleri de artmaktadır. Yazanoğlu'nun (2011) araştırmasından elde edilen sonuçlar da bu çalışmadan elde edilen sonuçlara benzer şekildedir. Araştırmacı, sosyoekonomik düzey yükseldikçe ilkokul birinci sınıf öğrencilerinin de okuma yazma becerilerinin arttığını gözlemlemiştir. Alt sosyoekonomik düzeyden gelen öğrencilerin ilk okuma yazma başarıları, üst sosyoekonomik düzeyden gelen öğrencilerin ilk okuma yazma başarılarından daha düşük olduğu sonucuna ulaşıımıştır. Bu araştırmalar sosyoekonomik düzeyin okuma yazma becerileri üzerinde etkili bir değişken olduğu sonucunu desteklemektedir.

KTE uygulanan ilkokul birinci sınıf mülteci öğrencilerin okul öncesi eğitim alıp almama değişkenine göre kelime tanıma düzeyi puanları karşılaştıııldığında 4. ve 6. seviye kelime listelerinde anlamlı fark bulunmazken, 1., 2., 3. ve 5. seviye kelime listelerinde anlamlı fark bulunmuştur. KTE'de yer alan bazı ses gruplarından oluşturulan kelime listelerinin okunmasındaki farklııklar, okul öncesi eğitim alıp almama durumuna göre anlamlı bulunmasa da okul öncesi eğitim alan mülteci öğrencilerin okul öncesi eğitim almamış mülteci öğrencilerin kelime tanıma düzeyi puanlarından daha yüksek puana sahip olduğu sonucuna ulaşıımıştır. İpekçi (2005) tarafından ilköğretim öğrencilerinin kullandıkları kelimeler üzerine yaptığı çalışmadan elde edilen bulgularla benzer şekilde olduğu görülmüştür. Araştırmacı okul öncesi eğitim alan çocukların, okul öncesi eğitim almamış çocuklardan daha fazla kelime bildiklerini tespit etmiştir. Bu durum, çocukların kelime servetlerinin gelişmesinde okul öncesinin önemli bir etken olduğunu göstermektedir. Buradan anlaşılacağı gibi, okul öncesi eğitim çocukların kullandıkları kelime sayısının artmasını sağlamaktadır. Kılıç'ın (2014) ilkokul birinci sınıflarda dinleme-konuşma-okuma-yazma gibi dil becerileri ile ilgili yaptığı çalışmanın sonuçlarına göre, öğrencilerin dil beceri düzeyleri arasında okul öncesi eğitim alıp almama durumlarına göre anlamlı bir farklılık bulunmuştur. Okul öncesi eğitimi alan öğrencilerin dil beceri düzeyleri, okul öncesi eğitimi almayan öğrencilere göre daha yüksek bulunmuştur. Obalar'ın (2009) bir araştırmasında, seshece-kelime-cümle okuma-anlamadan aldıkları puanlar okul öncesi eğitim alıp almama değişkenine göre dikkate alındığında okul öncesi eğitim alan öğrenciler lehine anlamlı bir farklılık göstermiştir. Bu 
durum da okul öncesi eğitim alma durumunun tüm dil becerileri üzerinde etkili bir değişken olduğu sonucunu desteklemektedir. Yapılan çalışmalar okul öncesi eğitim alıp almama ile kelime tanıma, kelime servetini geliştirme, kelime bilgisi arasında anlamlı farklığın olduğu yönünde tutarlı sonuçlar vermektedir.

Araştırma sonunda elde edilen bulgular ve alanyazın araştırmaları; hazırlanma ve uygulanma aşaması sürece dayalı olarak yapılan, iyi bir ölçme aracı niteliklerini taşıyan ve kelime tanımaya yönelik geliştirilen KTE'nin birinci sınıf mülteci öğrencilerin kelime tanıma düzeylerini belirlemede etkili olduğunu desteklemektedir. Yapılan çalışma, sosyoekonomik durumları farklı iki devlet okulunda öğrenim görmekte olan 32 Suriyeli mülteci ilkokul öğrenciye uygulanmasıyla sınırlıdır. Elde edilen bulgulardan genelleme yapılabilmesi için benzer çalışmanın daha büyük çalışma gruplarıyla yapılması önerilmektedir. Hazırlanma ve değerlendirilme aşamaları dikkate alınarak ilkokul birinci sınıf dışında farklı sınıf düzeylerinde, farklı ses gruplarıyla Kelime Tanıma Envanterleri hazırlanabilir. Mülteci öğrencilere yönelik kelime tanıma çalışmaları sadece Türkçe dersleriyle sınırlandırılmamalı, terimler, temalar ve kavramlarla ilgili kelime tanıma çalışmalarında diğer derslerden de yararlanılmalıdır. Öğretmenlerin, öğretim programının ve ders kitaplarının bu konuya daha fazla vurgu yapacak şekilde düzenlenmesi mülteci öğrencilerin kelime tanıma düzeylerinin gelişiminde rol oynayacak önemli etmenler olarak görülmektedir. Bu faktörlerin yanında ailelerin, çocuklarının kelime tanıma düzeylerinin gelişimi konusunda bilgi sahibi olmaları, çocukların kelime hazinelerinin geliştirilmesi gereken bir durum olduğunu kavramaları ve çocukların duygu ve düşüncelerini ancak sahip olduğu zengin kelime servetiyle ifade edebileceğini unutmamaları gerekmektedir. Bu nedenle ailelerin kelime tanıma düzeylerinin gelişimi hakkında bilgilendirilmesi sağlanmalıdır.

\section{Yazarların Katkı Oranı}

Illgili yazarın okuma-yazma ve kelime tanıma konusunda çalışmaları bulunmakta olup uzmanlık alanı çerçevesinde makalenin hazırlanmasında tüm katkı oranı yazara aittir.

\section{Çıkar Çatışması}

illgili çalışmada dolaylı veya dolaysız herhangi bir çıkar çatışması teşkil edebilecek durum ve ilişkiler bulunmamaktadır.

\section{Kaynaklar}

Ağır, O. ve Sezik M. (2015). Suriye'den Türkiye'ye yaşanan göç dalgasından kaynaklanan güvenlik sorunları. Birey ve Toplum Bahar Dergisi, 5(9), 95-123.

Aköz, Y. ve Toptaş, B. (2009, Mayıs). Ilköğretim 4. sınıf öğrencilerinin Türkçe dersinde öğrendiği kelimelerin anlamlarının karşılığının zihinsel olarak kavrama düzeylerinin incelenmesi. VIII. Ulusal Sınıf Öğretmenliği Eğitimi Sempozyumu'nda sunulmuş sözlü bildiri. Eskişehir Osmangazi Üniversitesi Eğitim Fakültesi, Eskişehir.

Akpınar, T. (2017). Türkiye'deki Suriyeli mülteci çocukların ve kadınların sosyal politika bağlamında yaşadıkları sorunlar. Balkan and Near Eastern Journal of Social Sciences, 3(3), 22-29.

Avşar Tuncay, A. (2017). Illkokul birinci sını öğrencilerine yönelik bir kelime tanıma envanteri tasarım ve geliştirme çalışması. Yayımlanmamış doktora tezi. Hacettepe Üniversitesi, Eğitim Bilimleri Enstitüsü, Ankara.

Avşar Tuncay, A. ve Dedeoğlu, H. (2020). Kelime tanıma envanteri tasarımı ve geliştirilmesi: Geçerlik ve güvenirlik çalışması. Mersin Üniversitesi Eğitim Fakültesi Dergisi, 16(1), 198-218.

Bader, L. A., \& Pearce, D. L. (2013). Bader reading and language inventory (7thed.). New Jersey: Pearson Education.

Baker, S. K., Simmons, D. C., \& Kame'enui, E. J. (1995). Vocabulary instruction: Synthesis of the research (Technical Report No: 13). Eugene, OR: National Center to Improve the Tools of Education.

Batur, Z. (2006). Illköğretim 8. sınıf öğrencilerinin Türkçe 6. ve 7. sınıf ders kitaplarından geçen bilinmeyen kelimeleri kazanım düzeyleri üzerine bir araştırma. Yayımlanmamış yüksek lisans tezi. Afyon Kocatepe Üniversitesi, Sosyal Bilimler Enstitüsü, Afyonkarahisar. 
Büyüköztürk, Ş. (2007). Sosyal bilimler için veri analizi el kitabı. Ankara: Pegem A Yayıncılık.

Büyüköztürk, Ş., Kılıç-Çakmak, E., Akgün, Ö. E., Karadeniz, Ş. ve Demirel, F. (2016). Bilimsel araştırma yöntemleri. Ankara: Pegem A Yayıncılık.

Cesur, O. (2005). (Kastamonu ilinde bir inceleme) Pansiyonlu ilköğretim okulu öğrencileri üzerinde kelime serveti araştırması. Yayımlanmamış yüksek lisans tezi. Abant İzzet Baysal Üniversitesi Sosyal Bilimler Enstitüsü, Bolu.

Çetinkaya, Ç. (2011). ilköğretim 4 ve 5. sınıf öğrencilerinin kelime kullanım sıklıkları üzerine bir araştırma. Yayımlanmamış doktora tezi. Gazi Üniversitesi, Eğitim Bilimleri Enstitüsü, Ankara.

Çıplak, M. (2005). Uşak merkez ilköğretim 5., 8. ve 11. sınıfların yazılı kelime hazinesinin belirlenmesi. Yayımlanmamış yüksek lisans tezi. Afyon Kocatepe Üniversitesi Sosyal Bilimler Enstitüsü, Afyonkarahisar.

Emin, M. N. (2016). Türkiye'deki Suriyeli çocukların eğitimi: Temel eğitim politikaları. İstanbul: Seta Yayınları.

Genç, B. (2010). Türkçe dersinde öğrenilen yeni sözcüklerin yazılı anlatımda kullanım durumu. Yayımlanmamış yüksek lisans tezi. Eskişehir Osmangazi Üniversitesi, Sosyal Bilimler Enstitüsü, Eskişehir.

Güneş, F. (2013). Türkçe öğretimi yaklaşımlar ve modeller. Ankara: Pegem Akademi Yayınları.

HBOGM

(2020).

http://hbogm.meb.gov.tr/dosyalar/izlemedegerlendirmerapor/2019/mobile/index.html\#p=1 40 adresinden 20. 07. 2020 tarihinde erişilmiştir.

İpekçi, A. (2005). Illköğretim 7. sınıf öğrencilerinin kelime serveti üzerine bir araştırma. Yayınlanmamış yüksek lisans tezi. Abant İzzet Baysal Üniversitesi, Sosyal Bilimler Enstitüsü, Bolu.

Karadağ, Ö. (2013). Kelime öğretimi. İstanbul: Kriter Yayınevi.

Karahan, F. (2007). Language attitudes of Turkish students towards the English language and its use in Turkish context. Journal of Arts and Sciences, 7, 73-87.

Kılıç, S. (2014). ilkokul birinci sınıfa devam eden 60-66-72 aylık öğrencilerin dil becerilerinin incelenmesi. Yayımlanmamış yüksek lisans tezi. Marmara Üniversitesi, Eğitim Bilimleri Enstitüsü, İstanbul.

Konur-Ergene, S. (2011). Orta öğretim 10. sınıf öğrencilerinin 9. sınıf Türk edebiyatı ve dil ve anlatım ders kitaplarındaki kelimeleri öğrenme düzeyleri. Yayımlanmamış yüksek lisans tezi. Gazi Üniversitesi, Eğitim Bilimleri Enstitüsü, Ankara.

Mutlu, N. (2016). Tasarım ve geliştirme araştırma modeli. M. Yaşar Özden ve L. Durdu (Yay. haz.). Eğitimde üretim tabanlı çalışmalar için nitel araştırma yöntemleri içinde (ss. 49-70). Ankara: Anı Yayıncılık.

Obalar, S. (2009). ilköğretim birinci sını öğrencilerinin ilk okuma yazma becerileri ile sosyal duygusal uyum ve zekâ düzeyleri arasındaki ilişkinin incelenmesi. Yayımlanmamış doktora tezi. Marmara Üniversitesi, İstanbul.

Ocak, S. (2007). Ilköğretim birinci sınıf öğrencilerinin dil gelişim düzeyleri ile ilk okuma yazma başarısı arasındaki ilişki. Yayımlanmamış yüksek lisans tezi. Marmara Üniversitesi, Eğitim Bilimleri Enstitüsü, i̇stanbul.

Özkan, E. (2012). Illköğretim 8. sınıf Türkçe ders kitaplarında öğrencilere kazandırılması hedeflenen sözcüklerin öğretimi ve iç sözlük ilişkisi. Yayımlanmamış yüksek lisans tezi. Mersin Üniversitesi, Eğitim Bilimleri Enstitüsü, Mersin.

Öztunç, S. (1994). Okuma kavramları testi'nin Türk çocuklarına uyarlanması. Yayınlanmamış Yüksek Lisans Tezi, Marmara Üniversitesi, İstanbul.

Richey, R. C., \& Klein, J. D. (2008). Research on design and development. In J. M. Spector, M. D. Merrill, J. van Merrienboer and M. P. Driscoll (Eds.), Handbook of research for educational communications and technology (pp. 748-757). Mahwah, NJ: Lawrence Erlbaum Associates Publishers.

Roe, B. D., \& Burns, P. C. (2007). Informal reading inventory. Preprimer to twelfth grade (7th edition). Boston, New York: Houghton Mifflin Company. 
Sağlam, H. í. ve illksen-Kanbur, N. (2017). Sınıf öğretmenlerinin mülteci öğrencilere yönelik tutumlarının çeşitli değişkenler açısından incelenmesi. Sakarya University Journal of Education, 7(2), 310-323.

Santoro, L. E., Chard, D. J., Howad, L., \& Baker, S. K. (2008). Making the very most of classroom readalouds to promote comprehension and vocabulary. The Reading Teacher, 61, 396-408.

Seydi, A. R. (2014). Türkiye'nin Suriyeli sığınmacıların eğitim sorununun çözümüne yönelik izlediği politikalar. SDÜ Fen Edebiyat Fakültesi Sosyal Bilimler Dergisi, 31, 267-305.

Shanker, J. L., \& Cockrum, W.A. (2014). Ekwall/Shanker reading inventory $\left(6^{\text {th }}\right.$ ed.). Boston, MA: Allyn \& Bacon.

Short, J. E. (2013). How much media? 2013. Report on American consumers. Southern California: Amy Blumenthal, Assistant Director of Media Relations.

Silvaroli, N. J., \& Wheelock, W. H. (2011). Classroom reading inventory (12 ${ }^{\text {th }}$ ed.). Boston, MA: McGraw-Hill.

Sinclair, M. (2001). Education in emergencies. In J. Crisp, C. Talbot \& D. B. Cipollone (Eds.), Learning for a future: Refugee education in developing countries. (pp. 1-83). Switzerland: UNHCR.

Stahl, S., \& Nagy, W.E. (2006). Teaching word meanings. Mahwah, New Jersey: Erlbaum.

Temur, T. (2006). Illköğretim 4 ve 5. sınıf öğrencilerinin yazı dilindeki kelime hazinelerinin bazı değişkenler açısından incelenmesi. Yayımlanmamış doktora tezi. Gazi Üniversitesi Eğitim Bilimleri Enstitüsü, Ankara.

Tuğluk, M. N. ve Avcı, Z. (2018). Türkiye'deki Suriyeli çocuklar ve eğitimleri. Z. Çetin (Ed.), Risk altındaki çocuklar ve eğitimleri içinde (ss. 149-163). Ankara: Eğiten Kitap.

Walpole, S., \& McKenna, M. C. (2006). The role of informal reading inventories in assessing word recognition. The Reading Teacher, 59(6), 592-594.

Woods, M. L., \& Moe, A. J. (2011). Analytical reading inventory: Comprehensive standards- based assessment for all students including gifted and remedial ( $9^{\text {th }}$ ed.). Boston, MA: Pearson Education.

Yalçın, S. K. (2005). Ilköğretim 1. ve 5. sınıf Türkçe ders kitaplarındaki sözvarlığı unsurlarının eğitsel açıdan değerlendirilmesi. Yayımlanmamış yüksek lisans tezi. Fırat Üniversitesi, Sosyal Bilimler Enstitüsü, Elâzığ.

Yazanoğlu, G. (2011). Ilköğretim birinci sını öğrencilerinde kelime dağarcığı gelişiminin ilk okuma yazma başarısı ve sosyoekonomik düzey ile ilişkisi. Yayımlanmamış yüksek lisans tezi. Uludağ Üniversitesi, Eğitim Bilimleri Enstitüsü, Bursa.

Yersüren, N. (2009). Türk dil bilgisinde kelime türleri (ad ve ad soylu kelimeler). Yayımlanmamış yüksek lisans tezi. Sakarya Üniversitesi, Sosyal Bilimler Enstitüsü, Sakarya.

\section{Introduction}

\section{Extended Abstract}

It is not easy to be in primary school, particularly in the first year, for Syrian refugee children who are studying with their peers who don't speak the same language. At home, these children whose parents don't even speak in Turkish are trying to learn reading and writing in the same class with their peers. One of the factors that make reading meaningful is recognition of the words in the reading text by the student. For a teacher it is extremely important that the student understands the meaning of the words in the text of the reading. In order to recognize and to make reading meaningful, it is necessary for the students to be directed to reading according to their level of word recognition by considering individual differences. For this reason, it was necessary to develop a vehicle in which the students could be identified independent, educational and anxiety level of the word recognition. It will be possible to identify and evaluate students' word recognition skills and word recognition with this assessment tool, which is prepared under the name of "Word Recognition Inventory" (WRI), and is used for primary school students and refugee children. 


\section{Method}

The study uses Type 1 development research of design and development research model to determine refugee students' word recognition levels. The study group in this research is composed of 32 refugee students who were the first grade primary school students in two different public schools who were chosen in convenience sampling method. According to the demographic properties of the students, 22 of them (68.75\%) were female while 10 of them (31.25\%) were male. The WRI which was developed by Avşar Tuncay (2017) to determine students' word recognition levels, and word recognition chart were used as the data collection tools. WRI, which was written in non-italic letters, contained 40 lists each of which is composed of 20 words. When words are read from the word list by the refugee students, the researcher recorded the words and whether they were read correctly or incorrectly to the "Word Recognition Chart." In word recognition charts, the words that the students read correctly are recorded with the symbol " $\mathrm{V}$ ", and the words they read incorrectly are recorded as they were read. Reading mistakes students make are mispronunciation, substitution, addition, deletion, inversion, repetition, and teachers' speech. In the study, independent group t tests were used to determine whether there was a difference in the normally distributed students according to their gender, age (month), socio-economic status and whether they attended kindergarten.

\section{Result and Discussion}

As a result of the research; It has been observed that when the word recognition inventory is read in a certain routine and order, it increases the reading motivation of refugee students and positively affects the level of word recognition and continuity. According to the results of the findings, the words that the refugee students read correctly were words such as "dede" (grandfather) containing repetitive sounds. Words such as "sarı" (yellow), "el" (hand), "at" (horse), "kuş" (bird), "nar" (pomegranate), "sel" (flood), "gül" (rose), "kitap" (book), "sevgi" (love), "yuva" (home), "ev" (house) were also the words that the students read correctly. As a result, it was seen that the children could read the words they heard frequently in their daily lives and in the family. But words of foreign origin and abstract words that do not make much sense for students are the most misread words. While there was no significant difference in word recognition scores for refugee students applying WRI in terms of age (months), it was found to be significantly different in terms of gender, socioeconomic status, and whether they had preschool education. As a result, it was determined that WRI was prepared and evaluated based on the process, had good measurement tool features and was developed to effectively determine the level of word recognition of refugee students. 